\title{
Introduction
}

\section{Climate and Security: Evidence, Emerging Risks, and a New Agenda}

François Gemenne, ${ }^{1}$ Jon Barnett, ${ }^{2}$ W. Neil Adger ${ }^{3}$ and Geoff Dabelko ${ }^{4}$

1 CEARC, University of Versailles Saint-Quentin-en-Yvelines, Guyancourt, France and CEDEM, University of Liège, Liège, Belgium

E-mail: francois.gemenne@sciencespo.fr

2 Geography and Resource Management, University of Melbourne, Melbourne, Australia

3 Geography, College of Life and Environmental Sciences, University of Exeter, Exeter, UK

4 Ohio University, Athens, Ohio, USA.

Submit date: $11 / 20 / 13$

Accept date: $1 / 26 / 14$

\begin{abstract}
Attention to the linkages between climate change and security has been punctuated in the past decade by high-level political discourses and a wide array of diverse publications. Yet these linkages remain often portrayed in a catastrophic and deterministic framing that does not make for rational debate on the impacts of climate change on human security. This paper seeks to engage social sciences in assessing the causes and consequences of climate change on human security, so that these can be supported by plausible and testable theories and models, and not just policy rhetoric. In this paper we review the state of knowledge on security dimensions of climate change; set out the major conclusions from the series of studies in this special issue, and point to emerging issues in the agenda for sustained research in this area.
\end{abstract}

\section{Introduction}

Climate change catastrophes in popular portrayal look like the biblical four horsemen of the apocalypse - war, famine, epidemics and mass dislocation. The underlying narrative behind such a portrayal of climate change impacts is about instability and uncertainty and a widely held belief that natural disasters are easily and straightforwardly attributed to wild weather or other forces of nature. Yet these dire apocalyptic visions are not likely to be a reality. Further, they do not make for rational debate on climate change and expositions of such apocalyptic futures are regularly criticized for making the climate debate alarmist (Lieserowitz, 2006; 0'Neill and Nicholson-Cole, 2009; Whitmarsh, 2011). 
Yet war, conflict, famine, epidemics and migration are real and significant for populations throughout the world. And if climate change affects human suffering through these mechanisms, then this human security dimension of climate change requires a long hard look. Each of the areas is, in fact, well understood with competing theories, explanations and approaches from across the social sciences. Conflict has been studied since the invention of armies and nations; migration is core to the science of demography; the study of the causes and consequences of famine has been overturned by economic and political theories of why and how they occur, not least through Sen's (1982) treatise on the subject.

Two other factors are added to this mix. First the debate of climate change, and environmental change in general, has been cast in environmental deterministic framing that continue a tradition of explaining social outcomes as driven by neoMalthusian imperatives and couched in terms of risk. Thus, for example, serious debate concerning the migration dynamics are affected by weather-related events has been swamped with discussions of climate refugees and a search for large numbers (Gemenne, 2011; Piguet, 2013). We argue that this highlighting of the issues of human insecurity has not been matched by an engagement of the social sciences that have plausible and testable theories of how climate change can affect the security of populations. Hence there is an urgent need for reengagement of economics, political science, international relations, demography, development studies and anthropology in assessing the causes and consequences of climate change on human security.

A second dimension of this arena is the issue of the role of the state in framing both climate change and its solution. There is a distinct unease and critique of the focus of climate change on risks to states brought about because of regional or global instability and resource scarcity. This concern stems from the emphasis on resources and territory underplaying the dimensions of individual vulnerability, equity and rights (Adger, 2010; Barnett, 2010) and from the securitization of climate change policy discourses such that solutions are skewed to those technologies and interventions that maintain the position of states themselves (Oels, 2013).

Both of these factors, environmental determinism and the concern over securitization, have we argue, hampered rigorous debate on some of the most critical dimensions of a changing future climate - the impact of those on instability and insecurity of populations experiencing them and adapting to a changing world. Hence in this paper we review the state of knowledge on security dimensions of climate change; set out the major conclusions from the series of studies in this special issue, and point to emerging issues in the agenda for sustained research in this area.

\section{A world of policy rhetoric and lagging science}

Policy attention to climate change and security has been punctuated in the past decade by high-level political discourses, such as in the UN Security Council, and in periodic assessment of climate change among the panoply of security risks facing states. This political activity has been supported by research produced by 
foreign policy, development, and security agencies, think tanks, and policy advocates. The analysis often takes the form of meeting reports and policy briefs (for example Dupont and Pearman 2006; WGBU 2007; 2008; CNA 2007 ; CSIS 2007; Funder et al., 2012; Smith and Vivekananda 2007; Carius et al. 2008; Stark et al. 2009; Rogers and Gulledge 2010; Werz and Conley 2012; Dabelko et al 2013). This body of grey literature highlights emerging issues, and elucidates the way different policy communities are framing climate change as a security issue. In effect, this literature both drove and now reflects an emerging international politics of climate change and security. Two high level debates in the United Nations Security Council, in April 2007, and July 2011 and the 2007 Nobel Prize for Peace awarded jointly to Al Gore and the Intergovernmental Panel on Climate Change (IPCC) raised attention on the international level. Myriad efforts highlighted links at national and regional levels.

Until recently this politics of climate change and security had not been accompanied by sustained engagement by scientific communities related to these fields. Much of the analysis made an implicit assumption the anticipated changes in natural systems would cascade into critical social problems and can present conventional national security problems. Yet, perhaps responding to the political interest in the subject, there has been a significant spurt in activity examining the phenomena of conflict and security, its causes and consequences, and its ethical and political ramifications in the context of climate variability and change (for example Adano et al., 2012; Benjaminsen et al., 2012; Brosnan et al. 2011; Gilman et al., 2011; Kumassa and Jones 2011; McLeman 2011; Raleigh 2011; Scheffran and Battaglini 2011; Smith 2011; Sunga 2011; Verhoeven 2011; O’Brien et al., 2011; Hsiang et al., 2012; Matthew 2012, Sygna et a., 2013).

All these studies do not a consensus make. The root cause of this lack of agreement is the concept of security, which is notoriously ambiguous and relative. Security studies recognizes that security can be seen as a concern for national security, but also in terms of groups of different scales, ranging from a concern for global, or common, security through to a concern for individual, or human, security. The risks to these different social entities can be construed quite narrowly as the risk of violent action, or quite broadly, to include risks to health, the environment, and livelihoods (Paris 2001). The issue of climate change ranges across this security schematic. Analysis highlights of ways climate change may threaten national security and nation states, human security at individual and community levels, and global security for global scope, even if the risks are not manifest uniformly across groups. Climate change is framed as a threat multiplier, a driver of diverse secondary risks, such as violent conflict, political instability, population displacements, poverty, and hunger.

Analysts from a range of disciplines apply diverse methods and theories of evidence to climate and security. This diversity in part accounts for divergent interpretations of the quality and extent of knowledge in this area. Physics, anthropology, statistics, economics, oceanography and human geography and their associated models, scenarios, ethnographies, and surveys can all be found in the literature on climate change and security. It is the resulting debates that we highlight in the remainder of this essay and this special issue 
Research clusters around four key issues within this broad topic of climate change and security. First, a considerable body of research centers on whether climate change may increase the risk of violence and the potential mechanisms through which climate change may increase that risk. Notable clustered contributions include a special issue of Political Geography in 2007 (Nordås and Gleditsch 2007), and more recent special issue of the Journal of Peace Research (Gleditsch 2012). Other key articles have sought to find broad patterns and statistical associations between climate, weather and conflict at diverse scales in order to provide predictive models of likely future risks (Hsiang et al. 2011). There is considerable debate about the extent to which climate change may increase the risk of violent conflict, with a few studies that make confident claims (among others see Hsiang and Burke, 2013), and quite a few which find little evidence for a causal connection between climate and conflict (see for example Gleditsch 2012).

A second and related focus of investigation concerns climate change and forced migration or displacement. These links are most often framed within the context of forced migration constituting a threat to security of states and people. Much of this research is summarized and developed in the UK Foresight review on migration and global environmental change (Foresight 2011). Some research examines the possibility that climate-induced migration may increase the likelihood of violent conflict (see for example Hartmann 2010, Raleigh 2011, Reuveny 2007). These and many other academic analyses conclude there is insufficient evidence to support confident statements about climate change driving migration that in turn may lead to violent conflict. Yet this linkage between climate change, migration and conflict is remains a persistent meme, repeatedly cited as a concern by NGOs, government agencies and civil society organizations (see for example Werz and Conley 2012; WBGU 2008).

Although there is much debate and little agreement about the extent to which climate change may cause conflict directly or indirectly through migration, there is more agreement, if less literature, when the causality is reversed. A small number of studies converge on a finding that climate change is a powerful driver of vulnerability to climate change (eg. Barnett 2006; Lind and Eriksen 2006; Tignino, 2011; Feitelson et al., 2012). Relatedly, there is increasing agreement that migration can be an important strategy for adapting to climate change (e.g., McLeman and Smit 2006; Tacoli 2009; Barnett and Webber 2010, Foresight 2011). In key policy realms, this role is has been recognized in the Cancún Framework for Adaptation, adopted in late 2010.

Finally, the risks climate change poses to human security are detailed in a small but largely consensual literature. A range of studies conclude, with varying degrees of evidence, that climate change poses risks to livelihoods, communities, and cultures (e.g. Barnett and Adger 2007; Lahiri-Dutt and Samanta 2007; Leary et al. 2008; Paavola 2008; Turner and Clifton 2009; Brklacich et al. 2010; Bronan 2010; Kumassa and Jones 2010; Badjeck et al. 2010; Mark et al. 2010; McLeman 2011; Mideksa 2010; Oluoko-Odingo 2011; Adger et al., 2011). 
Beyond these four main areas of investigation on the subject of climate change and security, there is an array of issues that have yet to be much explored. The purpose of this special issue of Climatic Change is to advance knowledge about all of these dimensions of climate change and security, through a series of papers initially presented and discussed at a workshop hosted by the Institute for Sustainable Development and International Relations (IDDRI), Sciences Po, in Paris on May 3-4, 2012, sponsored by the Directorate for Strategic Affairs within the French Ministry of Defence, the UK Department of Energy and Climate Change, and the British Council.

These articles have since been revised and peer-reviewed for this special issue. They attempt to review the evidence that has been presented so far, assess its robustness, and outline the challenges ahead. They aim to make more robust the evidence base and while engaging head on claims that are often made about the security risks of climate change. Together, they provide insights into aspects of climate-security nexus that have often been under-researched due to the lack of engagement in the area by the broad fields of social science

\section{Contributions of this special issue}

Articles in this special issue can be clustered into four dimensions of emerging research on climate change and security.

First, some authors engage epistemological challenges of producing knowledge about future changes in complex socio-ecological systems. Scenarios are a principal method used to explore the future in both climate change and security studies. Lewis (2013) provides an overview of the different kinds of scenarios used, and their strengths and limits. Indeed, many of the scenarios utilized so far have failed to account sufficiently for uncertainty, and lack clarity about the timescales and scales of change. As a result, most yield very general conclusions, with little relevance for policy-making. Another common method to explore the future impacts of climate change on security is cartography, and especially hotspots mapping. Hotspots are regions of the world considered particularly vulnerable to climate impacts. This climate mapping is paired with political, economic, and social conditions to identify regions at greatest security risk. Mapping exercises seek to facilitate policy decisions by drawing policy-makers' attention to regions that appear of the most concern. The paper by de Sherbinin (2013) reviews the different approaches and data used to conduct such mapping exercises. It also raises questions regarding the limitations, usefulness, and added value compared to other methods - such as scenarios.

Second, climate change poses diverse risks to national security. These challenges include a possible increased risk of violent conflict in some countries, which in turn poses challenges to the security policies of neighboring countries, the United Nations Security Council, and countries that contribute to peacekeeping missions. Hsiang and Burke (2013) examine the correlation between climatological changes and conflict outcomes in 50 quantitative studies, at different scales, and find a strong association between climatic changes and conflicts. 
While conflict is certainly the most obvious risk to national security, other crucial elements of national security are also affected by climate change. They also include non-military threats, such as to infrastructure critical to the functioning of states such as energy and water systems, the impacts of extreme events, and the vulnerability of key sectors. King and Gulledge (2013) explore different ways in which energy security could be at risk through threats to energy systems and infrastructure. They find little evidence of direct climate impacts on energy supply, but contend that threats on energy security will come from the social instability - as identified in Hsiang and Burke (2013) - or from the effects of climate mitigation and adaptation technology choices.

Third, climate change will transform geopolitical landscapes. In particular, security issues can arise relating to conflicts (or enhanced cooperation) between countries around transboundary issues. Examples include shared waters and resources of the Arctic, international rivers, risks associated with an expansion of nuclear power as a climate mitigation response, or cross-border flows after extreme events. Kallis and Zografos (2013) question the simple narrative of socalled water wars, linking climate change and security via water. Integrating research from diverse disciplines, they show the complex interactions between water scarcity, transboundary basins, vulnerability, and conflict, and suggest that these could actually lead to increased cooperation under climate change, provided precautionary no-regrets policies are taken.

Finally, while most of the literature considers how the effects of climate change need to be accounted for in security policies, the opposite relationship also needs to be examined. How will security issues affect climate policies? Security considerations will affect the way political institutions respond to climate change, and conflict-affected countries will often be more vulnerable to climate change. Matthew (2013) examines UN peacebuilding missions and notes that since 1948, the overwhelming majority of these missions have occurred in regions that were highly vulnerable to climate change impacts. Yet climate policies - that is, mitigation and adaptation policies - are generally excluded from peacebuilding operations, and the article offers constructive suggestions to foster this integration.

\section{Ongoing challenges for a science of climate and security}

This special issue highlights neglected aspects of the climate-security nexus. Doing so, it raises as many questions as it answers. First, the literature on climate change and security tends to focus on the causes for conflict, rather than on reasons for peace. The framing of climate change as a security issue was also an attempt, for many, to prompt states to address climate change more urgently and more seriously. If the climate-security nexus is to be studied for what it is, rather than for what it can achieve policy-wise, the framing of the nexus will matter. More emphasis needs to be put on the factors for peace and cooperation, on the capabilities of people and institutions, rather than just on the threats and risks as it has been the case so far. 
Second, there is some evidence for a statistical correlation between climatic changes and conflicts, the field of inquiry remains weak on theories that explain the pathways by which changes in climate lead to various security problems. Evidence without theory is blind, just as theory without evidence is meaningless. As we build increasingly robust evidence that changes in climatic conditions can lead to conflicts, we remain unable to provide clear explanations as to how this can happen. The interpretation of many studies in this area also contains considerable confusion of correlation and causation when it comes to the linkages between climate change and security. Conflicts can only be avoided if we know how they happen, and it is only thanks to theoretical models that we will be able to think about the changes that need to be made to avoid the initiation of pathways that end up in conflict.

Part of the explanation for this lack of theoretical models can be found in the disciplinary divide between qualitative and quantitative studies, as argued recently by Solow (2013). Though more cooperation is obviously needed between quantitative and qualitative scholars, this explanation is only part of the answer. There is not one satisfactory theory that could link together climate change and conflict. Broad scale statistical studies, though they provide robust statistical correlation, can only yield to generalized understandings, which are unlikely to explain what happens in any given case.

Quantitative studies, for example, show that both increases and decreases in rainfall can lead to conflict. This divergence seems impossible to explain with one single theory that would explain how changes in rainfall lead to conflict. Instead, what is needed are multiple, nuanced theories. These approaches could explain, for example, help us understand how rainfall increases in rangelands in sub-Saharan Africa leads to increasing communal violence among pastoralists, as opposed to how decreasing rainfall leads to increasing violent protests about water pollution in northern China. These multiple theories would put a strong emphasis on the context, showing how climate change and security interplay with each other in particular places and particular circumstances. These theories can only be built if social sciences are mobilized to study the causal processes and pathways between changes and various social outcomes.

Third, power remains often absent from the literature on climate and security yet it is the elephant in the room. Vulnerability is a function of power: the power of political processes and markets to deny some groups the freedoms and opportunities that they need to make choices in their interests and to act on those decisions, and the power of institutions to appropriate and divert processes that aim to overcome vulnerability. Vulnerability revolves around power, even at the most basic level. Individuals and community may exhibit measurable metrics of vulnerability and exposure doe to their economic and geographical marginality, yet also resist power and interventions through tenacity, strategic, and resourceful ways in which even the very destitute act in times of crisis to reduce their underlying vulnerability. Any theory that would seriously attempt to explain how climate change can lead to security issues will need to place power front and center. 
Finally, most of what we know about the relationship between climate change and security comes from the observation of patterns of the past. Yet there is only so much we can learn from the past: given the continuous rise of greenhouse gas emissions and our failure to curb them, the scenario of regional climate changes by the end of the century that are unprecedented in human history becomes increasingly likely. These scenarios brings about the possibility of tipping points in both regional climate, such as the Asian monsoon, or the loss of Greenland ice mass, that fundamentally alter the patterns of the past. To put it another way, the way human societies will react to climate change could also reach tipping points in $\mathrm{a}+4^{\circ} \mathrm{C}$ scenario. Hence, in order to get realistic pictures of future security impacts, the method of historical inference will not suffice, and scenarios will be of primary importance.

\section{Conclusions}

In many parts of the world, climate change does not necessarily pose immediate security threats. What matters, and what may matter in the near term, is the way various institutions respond to the idea of climate change.

There is the possibility that states would react to climate change by increasing their defense capacities and military budgets rather than by also addressing the root causes of the problem. Security communities will adapt within a security perspective to new climate realities. Yet if response is limited to security responses, fundamental underlying climate threats will remain neglected.

With efforts to address climate change directly, it is critical to ask, how will food, water, and energy markets and governments respond to anticipated scarcities caused by climate change and the amplification of climate extremes? Mitigation and adaptation policies, done poorly, may exacerbate power asymmetries and dispossess vulnerable communities in ways that amplify various kinds of insecurities (Dabelko et al. 2013). These concerns revolve around land use changes and changes in access to carbon stocks in forests associated with Reduced Emissions from Deforestation and Forest Degradation Projects (REDD+), or of the impacts on livelihoods associated with adaptation infrastructure projects, or of land grabbing and forced migration in the name of reducing vulnerability.

Thus one can see the scope for climate response policies that can make conditions worse in ways that connect directly to security in its human, national, and global dimensions. But there is also scope for responses that can facilitate win-win outcomes for human security, adaptation, and conflict mitigation. These efforts will need to be guided by the theories and evidence we have about climate change and security in particular places.

\section{References}


Adano, W.R., T. Dietz, K. Witensburg, and F. Zaal, 2012: Climate change, violent conflict and local institutions in Kenya's drylands. Journal of Peace Research, 49(1), 65-80.

Adger, W.N., 2010: Climate change, human well-being and insecurity. New Political Economy, 15(2), 275-292.

Adger, W.N., J. Barnett, F.S. Chapin III, and H. Ellemor, 2011: This must be the place: Under representation of identity and meaning in climate change decision-making. Global Environmental Politics, 11(2), 1-25.

Badjeck, M., E. Allison, A. Halls, and N. Dulvy, 2010: Impacts of climate variability and change on fishery-based livelihoods. Marine Policy, 34, 375-383.

Barnett, J., 2006: Climate change, insecurity, and injustice. In: Fairness in adaptation to climate change. [Adger, W. N., J. Paavola, S. Huq, and M.J. Mace (eds.)]. MIT Press, Cambridge MA, 115130.

Barnett, J., 2010: Human rights and vulnerability to climate change. In: Human Rights and Climate Change. [Humphreys, S. (ed.)]. Cambridge University Press, Cambridge, pp. 257-271.

Barnett, J. and W.N. Adger, 2007: Climate change, human security and violent conflict. Political Geography, 26(6), 639-655.

Barnett, J. and M. Webber, 2010: Migration as adaptation: Opportunities and limits. In: Climate change and displacement: Multidisciplinary perspectives. [McAdam, J. (ed.)]. Hart Publishing, Oxford, pp. 37-56.

Benjaminsen, T.A., Alinon, K., Buhaug, H., Buseth, J.T. 2012: Does climate change drive land-use conflicts in the Sahel? Journal of Peace Research 49, 97-111.

Brklacich, M., M. Chazan, and H.G. Bohle, 2010: Human security, vulnerability, and global environmental change. In: Global environmental change and human security. [Matthew, R., J. Barnett, B. McDonald, and K. O’Brien (eds.)]. MIT Press, Cambridge MA, 35-76.

Bronen, R., 2010: Forced migration of alaskan indigenous communities due to climate change. In: Environment, forced migration and social vulnerability. [Afifi, T. and J. Jager(eds.)]. Springer, Berlin, pp. 87-98.

Brosnan, I.G., T.M. Leschine, and E.L. Miles. 2011. Cooperation or conflict in a changing Arctic? Ocean Development and International Law 42(1-2):173-210.

Carius, A., Tanzler, D. and Maas, A. 2008. Climate Change and Security: Challenges for German Development Cooperation. Deutsche Gesellschaft fur Technische Zusammenarbeit (GTZ) GmbH: Eschborn.

Center for Strategic and International Studies (CSIS) 2007. The Age of Consequences: The Foreign Policy and National Security Implications of Global Climate Change. Washington D.C., CSIS.

CNA. 2007: National Security and Threat of Climate Change. Alexandria, VA, CNA Corp.

Dabelko, G., L. Herzer, S. Null, M. Parker, and R. Sticklor, Eds. 2013: Backdraft: The Conflict Potential of Climate Change Adaptation and Mitigation. Environmental Change and Security Program Report 14(2): 1-56.

De Sherbinin, A. 2013. Climate change hotspots mapping: What have we learned? Climatic Change, 10.1007/s10584-013-0900-7.

Dupont, A., and Pearman, G. (2006). Heating up the planet: climate change and security. Lowy Institute Paper 12. Double Bay: The Lowy Institute.

Feitelson, E., A Tamimi, and G. Rosenthal, 2012: Climate change and security in the IsraeliPalestinian context. Journal of Peace Research, 49(1), 241-257.

Foresight 2011, Migration and Global Environmental Change Final Report. London: The Government Office for Science.

Funder, M., Ravnkilde, S. and Ginsborg, I. 2012. Addressing Climate Change and Conflict in Development Cooperation: Experiences from Natural Resource Management, Danish Institute for International Studies: Copenhagen.

Gemenne, F. (2011) Why the numbers don't add up: A review of estimates and predictions of people displaced by environmental changes. Global Environmental Change 21 (supp 1), S41S49.

Gilman, N., D. Randall, and P. Schwartz, 2011: Climate change and security. In: Oxford handbook of climate change and society. [Norgaard, R., J. Dryzek, and D. Schlossberg(eds.)]. Oxford University Press, Oxford.

Gleditsch, N. 2012. Whither the weather? Climate change and conflict, Journal of Peace Research 49(1): 3-9. 
Hartmann, B. 2010. Rethinking climate refugees and climate conflict: Rhetoric, reality and the politics of policy discourse, Journal of International Development, 22(2): 233-246.

Hsiang, S. and M. Burke. 2013. Climate, conflict, and social stability: what do the evidence say? Climatic Change, 10.1007/s10584-013-0868-3.

Hsiang, S., K. Meng, and M. Cane, 2011: Civil conflicts are associated with the global climate. Nature 476, 438-441.

Kallis, G. and C. Zografos. 2013. Hydro-climatic change, conflict and security. Climatic Change, 10.1007/s10584-013-0893-2.

King, M. and J. Gulledge. 2013. Climate change and energy security: an analysis of policy research. Climatic Change, 10.1007/s10584-013-0895-0.

Kumssa A. and Jones J.F., 2011: Climate change and human security in Africa. International Journal of Sustainable Development and World Ecology, 17, 453-461.

Lahiri-Dutt, K. and G. Samanta, 2007: Like the drifting grains of sand': Vulnerability, security and adjustment by communities in the charlands of the damodar river, India. South Asia: Journal of South Asian Studies, 30(2), 327-349.

Leary, N., C. Conde, J. Kulkarni, A. Nyong, and J. Pulhin (eds.), 2008: Climate change and vulnerability. Earthscan, London, pp. 428.

Leiserowitz, A., 2006. Climate change risk perception and policy preferences: the role of affect, imagery, and values. Climatic Change 77, 45-72.

Lewis, K., 2013. Climate science in climate security scenarios. Climatic Change, 10.1007/s10584013-0945-7.

Lind, J., and S. Eriksen, 2006: The impacts of conflict on household coping strategies: evidence from Turkana and Kitui districts in Kenya. Die Erde, 137(3), 249-270.

Mark, B.G., J. Bury, J.M. McKenzie, A. French, and M. Baraer, 2010: Climate change and tropical andean glacier recession: Evaluating hydrologic changes and livelihood vulnerability in the Cordillera Blanca, Peru. Annals of the Association of American Geographers, 100(4), 794-805.

Matthew, R. (2013), Integrating climate change into peacebuilding. Climatic Change, 10.1007/s10584-013-0894-1.

Matthew, R. (2012), Environmental Change, Human Security and Regional Governance: The Case of the Hindu Kush-Himalaya Region, Global Environmental Politics 12(3), 100-118.

McLeman, R.A. (2011) Settlement abandonment in the context of global environmental change. Global Environmental Change, 21 (supp) S108-S120.

McLeman, R. and B. Smit (2006). Migration as an adaptation to climate change. Climatic Change 76: 31-53.

Mideksa, T.K., 2010: Economic and distributional impacts of climate change: The case of ethiopia. Global Environmental Change, 20(2), 278-286.

Nordås, R. and Gleditsch, N. 2007. Climate Change and Conflict, Political Geography 26(6): 627 638.

O'Brien, K., A.L. St Clair, and B. Kristoffersen (eds.), 2010: Climate Change, Ethics and Human Security. Cambridge University Press, Cambridge.

Oels, A., 2013: Rendering climate change governable by risk: From probability to contingency. Geoforum, 45, 17-29.

Oluoko-Odingo A.A., 2011: Vulnerability and adaptation to food insecurity and poverty in kenya. Annals of the Association of American Geographers, 101, 1-20.

O'Neill, S., Nicholson-Cole, S. (2009) "Fear Won't Do It" Promoting Positive Engagement With Climate Change Through Visual and Iconic Representations. Science Communication 30, 355379.

Paavola, J., 2008: Livelihoods, vulnerability and adaptation to climate change in Morogoro, Tanzania. Environmental Science and Policy, 11(7), 642-654.

Paris, R. 2001. Human Security: Paradigm Shift or Hot Air? International Security, 26, 87-102

Piguet, E. 2013: From "primitive migration" to "climate refugees" - The curious fate of the natural environment in migration studies. Annals of the Association of American Geographers, 103(1), 148-162.

Raleigh, C., 2011: The search for safety: the effects of conflict, poverty and ecological influences on migration in the developing world. Global Environmental Change, 21(sup.1), S82-S93

Reuveny, R. 2007. Climate change-induced migration and violent conflict, Political Geography 26(6): 656-673

Rogers, W. and Gulledge J., 2010: Lost in Translation: Closing the Gap Climate Science and National Security Washington, Center for New American Security. 
Sen, A. (1982) Poverty and famines: an essay on entitlement and deprivation. Oxford University Press, Oxford.

Sheffran, J. and Battaglini, A. 2011: Climate and conflicts: the security risks of global warming. Regional Environmental Change 11(supp), 27-39.

Smith, P.J. 2011. The geopolitics of climate change: power transitions, conflict and the future of military activities. Conflict, Security and Development 11(3): 309-334.

Smith D, Vivekananda J 2007: A Climate of Conflict: The Links Between Climate Change, Peace and War. London: International Alert.

Solow, A. 2013: A call for peace on climate and conflict. Nature 497: 179-180.

Stark, J., Mataya, C. and Lubovich, K. 2009. Climate Change, Adaptation and Conclict: A Preliminary Review of the Issues. CMM Discussion paper 1, USAid, Washington.

Sunga, L. (2011): Does climate change kill people in Darfur? Journal of Human Rights and the Environment 2(1): 64-85.

Sygna, L., K. O'Brien, and J. Wolf (eds.), 2013: A Changing Environment for Human Security. Transformative Approaches to Research, Policy and Action. Routledge, London.

Tacoli, C., 2009: Crisis or adaptation? migration and climate change in a context of high mobility. Environment and Urbanization, 21(2), 513-525.

Tignino, M., 2011: The right to water and sanitation in post-conflict peacebuilding. Water International, 36(2), 242-249.

Turner, N.J. and H. Clifton, 2009: "It's so different today": Climate change and indigenous lifeways in british columbia, canada. Global Environmental Change, 19(2), 180-190.

Verhoeven, H., 2011: Climate change, conflict, and development in Sudan: global neo-malthusian narratives and local power struggles. Development and Change, 42(3), 679-707.

WBGU (German Advisory Council on Global Change), 2007. World in Transition: Climate Change as a Security Risk, Berlin, WBGU.

WBGU 2008. Climate Change as a Security Risk. London: Earthscan.

Werz, M. and Conley, L. 2012. Climate Change, Migration and Conflict, Center for American Progress, Washington DC.

Whitmarsh, L. (2011) Scepticism and uncertainty about climate change: dimensions, determinants and change over time. Global Environmental Change 21, 690-700. 


\section{University Library}

\section{- M M I N E R VA A gateway to Melbourne's research publications}

Minerva Access is the Institutional Repository of The University of Melbourne

Author/s:

Gemenne, F;Barnett, J;Adger, WN;Dabelko, GD

Title:

Climate and security: evidence, emerging risks, and a new agenda

Date:

2014-03-01

Citation:

Gemenne, F., Barnett, J., Adger, W. N. \& Dabelko, G. D. (2014). Climate and security: evidence, emerging risks, and a new agenda. CLIMATIC CHANGE, 123 (1), pp.1-9. https:// doi.org/10.1007/s10584-014-1074-7.

Persistent Link:

http://hdl.handle.net/11343/283211 